\title{
Is It Time For a Coherent Political Question Doctrine in South Africa? Lessons from the United States
}

\author{
Mtendeweka Mhango
}

School of Law, University of the Witwatersrand, Johannesburg, South Africa mtendeweka.mhango@wits.ac.za

\begin{abstract}
This article describes the development and current status of the political question doctrine theme in South African jurisprudence. It does this through a comparative discussion of the application of this doctrine in the United States. The purpose of this comparative examination is twofold: the first is to gain insight into the origins, trends and early application of the political question doctrine. The second is to gain insight into the challenges and best practices in relation to the application of the political question doctrine elsewhere. The paper argues that while the political question doctrine theme exists in South African jurisprudence, this has not matured into a clear and transparent doctrine. It calls for the development of a clear doctrine for South Africa and offers some recommendations.
\end{abstract}

\section{Keywords}

political question doctrine - South Africa - Kpegah - separation of powers

\section{Introduction}

In 2010, President Jacob Zuma made an important speech at the farewell dinner of the former Chief Justice Sandile Ngcobo of the South African Constitutional Court (Court), where he discussed, among other things, the principle of separation of powers and its effects on the resolution of political questions. Zuma said the following: 
In paying tribute to our former chief justice, we reiterate our firm belief in the principles of the rule of law, the separation of powers, and judicial independence. We also reiterate our view that there is a need to distinguish the areas of responsibility between the judiciary and the elected branches of the state, especially with regards to policy formulation. The executive has the sole discretion to decide policies for government. We respect the powers and role conferred by our Constitution on the legislature and the judiciary. At the same time, we expect the same from these very important institutions. The executive should be allowed to conduct its administration and policy-making work as freely as it could. The powers conferred on the courts could not be regarded as superior to the powers resulting from a mandate given by the people in a popular vote. To provide support to the judiciary and free the courts to do their work, it would help if political disputes were resolved politically. ${ }^{1}$

The above statement is perhaps the most recent reference to the theme of the political question doctrine by a politician in South Africa. ${ }^{2}$ The political question doctrine is a function of the separation of powers principle and provides that there are certain constitutional questions that are constitutionally committed to the elected branches of government for resolution. ${ }^{3}$ As a result, such

1 I.M. Rautenbach, 'Policy and Judicial Review - Political Questions, Margins of Appreciation and the South African Constitution', 1 Journal of South African Law (2012), 20-35, at 34.

2 For a discussion about former President Paul Kruger's views on judicial review and the theme of the political question doctrine see, J. Dugard, Human Rights and the South African Legal Order (Princeton, NJ: Princeton University. Press, 1978), at pp. 14-36. See also A. Endicott, 'The Judicial Answer? Treatment of the Political Question Doctrine in Alien Tort Claims', 28 Berkeley Journal of International Law (2010), 537-555, at 538 (arguing that the political question doctrine represents a judicial effort to ensure that the courts do not hamper the functioning of the political branches); and K. O'Regan, 'A Forum for Reason: Reflections on the Role and Work of the Constitutional Court', 28 South African Journal of Human Rights (2012), 116-134, at 132 (arguing that courts in South Africa must exercise restraint in the area of policy formulation and not impede the functioning of government because the legislature, and indirectly, the executive are democratically elected arms of government, whose office is determined by popular vote).

3 See M. Redish, 'Judicial Review and the Political Question', 79 Northwestern Law Review (1984), 1031-1061; K. Breedon, 'Remedial Problems at the Intersection of the Political Question Doctrine, the Standing Doctrine and the Doctrine of Equitable Discretion', 34 Ohio Northern University Law Review (2008), 523-566; H. Wechsler, 'Principles, Politics, and Fundamental Law (Cambridge, MA: Harvard University Press, 1961), at pp. 11-14; K. Yoshino, 'Restrained Ambition in Constitutional Interpretation', 45 Willamette Law Review (2009), 555-564, at $557-559$ (arguing that the political question doctrine is a doctrine of justiciability); and 
questions are non-justiciable and require the judiciary to abstain from deciding them if doing so would intrude upon the functions of the elected branches of government. ${ }^{4}$ The underlying theme is that such questions must find resolution in the political process. ${ }^{5}$

In the above statement, Zuma called for the development of a political question doctrine for South Africa. Significant support for this call can be found in the jurisprudence and academic commentary in South Africa and abroad. ${ }^{6}$ One notable support is the United States Supreme Court case in Marbury $v$ Madison, where it held that "the province of the court is not to inquire how the executive performs duties in which they have discretion; that questions in their nature political are not appropriate for this court". ${ }^{7}$ In subsequent cases, United States federal courts have consistently ruled that the judiciary is barred from deciding cases that revolve around policy choices and value determinations constitutionally committed for resolution to the elected branches of government. ${ }^{8}$ There is also support for Zuma's call in the case law from Uganda, Nigeria and Ghana. These cases provide the basis for the view that the resolution of political questions, which are committed by a Constitution to the

\footnotetext{
S. LaTourette, 'Global Climate: A Political Question?', 4o Rutgers Law Journal (2008), 219-284 (arguing that the political question doctrine is a function of the separation of powers).

6 See Marbury v. Madison, 5 U.s. (1 Cranch) 137 (1803); E. Nwauche, 'Is the End Near for the Political Question Doctrine in Nigeria?', in C. Fombad and C. Murray (eds), Fostering Constitutionalism in Africa (Pretoria: PULP Press, 2010), pp. 31-6o; Z. Motala and C. Ramaphosa, Constitutional Law: Analysis and Cases (Oxford: Oxford University Press, 2002); Ghana Bar Association v. Attorney General [2003-2004] SCGLR 250; In re: Certification of the Constitution of the Republic of South Africa, 1996 (10) BCLR 1253 (CC); Mazibuko v Sisulu 2013 (4) SA 243 (wCC); AG v. Tinyefuza, Const. Appeal No. 1 of 1997 (s.c.); A. Bickel, The Least Dangerous Branch (Indianapolis, In: Bobbs-Merrill, 1962); P. Mulhern, 'In Defense of the Political Question Doctrine', 137 University of Pennsylvania Law Review (1988), 97-176; F.W. Scharpf, 'Judicial Review and the Political Question: A Functional Analysis', 75 Yale Law Journal (1966), 517-597; M. Tushnet, 'Law and Prudence in the Law of Justiciability: The Transformation and Disappearance of the Political Question Doctrine', 8o North Carolina Law Review (2002), 1203-1235; and C. Okpaluba, 'Justiciability, Constitutional Adjudication and the Political Question in a Nascent Democracy: South Africa', 18 South African Public Law (2003), 331-348 (part 1) and 19 South African Public Law (2004) 114-131 (part 2); S. Seedorf and S. Sibanda, 'Separation of Powers', in S. Woolman, T. Roux, J. Klaaren, A. Stein, M. Chaskalson and M. Bishop (eds), Constitutional Law of South Africa, 2nd edn (Cape Town: Juta, 2008), pp. $12-50$.

7 Marbury, supra note 6 at 170.

8 See Corrie v. Caterpillar, 503 F.3d 974, 980 (9th Cir. 2007).
}

4 Ibid.

5 Ibid. 
elected branches of government, rests entirely with those branches. ${ }^{9}$ Further, Zuma finds support in, among others, Tushnet, a renowned advocate of the political question doctrine, who has rightly argued that the judiciary should be restrained from resolving issues that other branches are better suited to resolve. ${ }^{10}$

Proponents of Zuma's call have dismissed detractors of the political question doctrine, whose opposition is largely premised on two connected assumptions: that the judiciary is the only institution with authority and capacity to interpret the Constitution; and that to limit such judicial monopoly threatens the rule of law in conflict with the supremacy of the Constitution. ${ }^{11}$ Instead, proponents defend the political question doctrine on the basis that the judiciary shares responsibility for interpreting the Constitution with the elected branches of government and deem the doctrine as one of the devices the judiciary employs to define this division of responsibility. ${ }^{12}$

It is important to mention that prior to 1994, South Africa was governed under the system of parliamentary supremacy in which the judiciary enjoyed limited review powers. In reviewing legislative acts, judicial powers were limited to determining whether parliament had complied with legislative procedures and not the substance of its acts. The judiciary could not invalidate the conduct of government on the basis that it violated basic human rights because there was no bill of rights. Under this system courts were required to abide by the wishes of the political majority in Parliament. ${ }^{13}$ Hence, the major

9 R. Barkow, 'More Supreme than Court? The Fall of the political Question Doctrine and the Rise of Judicial Supremacy', 102 Columbia Law Review (2002), 237-334.

10 Tushnet, supra note 6 at 1232; Bickel, supra note 6, Scharpf, supra note 6; and Wechsler, supra note 6. See also J. Jaffe, 'The Political Question Doctrine: An Update in Response to Recent Case Law', 38 Ecology Law Quarterly (2011), 1033-1066, at 1037.

11 See Mulhern, supra note 6 at 99-100; Rautenbach, supra note 1 at 28; Reddish, supra note 3 at 101 .

12 Mulhern, supra note 6 at 101; I. Currie and J. De Waal, The Bill of Rights Handbook (Cape Town: Juta, 2005), p. 394 note 184 (arguing that courts are not solely responsible for interpreting the Constitution); and I. Imam, A.O. Sambo, W. Egbewole and A.B. Abdulkadir, 'Judicial Activism and Intervention in the Doctrine of Political Questions in Nigeria: An Analytical Exposition', 1 African Journal of Law and Criminology (2011), 50-69; L. Fisher and N. Devins, Political Dynamics of Constitutional Law (St. Paul, MN: West, 1992), at p. 10; Tinyefuza, supra note 6 (holding that the judiciary is not the only constitutional organ with interpretive power); and United States $v$ Butler, 297 U.s. 1, 87 (1936) (Stone dissenting) (arguing that courts are not the only agency of government that must be assumed to have the capacity to govern).

13 I. Currie and J. De Waal, The New Constitutional and Administrative Law (Cape Town: Juta, 2001), at p. 64 . 
constitutional change that occurred in 1994 is that parliamentary supremacy was replaced with the system of constitutional supremacy, where the judiciary enjoys wide judicial review powers and is commanded to enforce Constitution by striking down decisions of the political majority in Parliament. ${ }^{14}$

The seminal case on judicial review is Marbury. There, the Supreme Court held that "it is, emphatically, the province and duty of the judicial department to say what the law is". ${ }^{15}$ With these words, Marbury laid the foundation for the exercise of judicial review in modern democracies across the globe, including South Africa. ${ }^{16}$ In her study, Barkow observed that the above phrase in Marbury 'could be read in isolation to establish limitless constitutional authority in the Supreme Court to answer all constitutional questions. ${ }^{17}$ To the contrary, Barkow argues, this eloquent excerpt from Marbury cannot be taken out of context or literary; that the duty "to say what the law is" does not necessarily imply a judicial monopoly on constitutional interpretation. ${ }^{18}$ For Barkow, this duty leaves room for absolute deference to the constitutional interpretation of the political branches because the Constitution may contain provisions that dictate an interpretive role for the political branches. ${ }^{19}$ In this regard, she contends that Marbury itself contains the seeds for the view that the authority to answer some constitutional questions rests entirely with the political branches. ${ }^{20}$ Similarly, Post and Siegel in their commentary on the notion of popular constitutionalism, which is the idea that people assume active and ongoing control over the interpretation and enforcement of constitutional law, ${ }^{21}$ offer another explanation for the proposition of the shared responsibility on constitutional interpretation among the three branches of government. They argued that 'elections are a critical moment for expressing the people's

\footnotetext{
14 Ibid.

15 Marbury, supra note 6 at 177.

16 Marbury contributed to the development of the concept of judicial review in South Africa during the late 180os. See Leyds v. Brown, 4 Off Rep 17 (1897) (where relying on Marbury the Supreme Court of the Transvaal declared that it had the power of judicial review); and Dugard, supra note 2 at $18-25$.

17 Barkow, supra note 9 at 239. See also M. Paulsen, 'Judging Judicial Review: Marbury in the Modern Era', 101 Michigan Law Review (2003), 2706-2743.

18 Ibid. See also Currie and De Waal, supra note 13, at 394; Fisher and Devins, supra note 13, at 10.

19 Ibid. See also H.P. Monaghan, 'Marbury and the Administrative State', 83 Columbia Law Review (1983), 1-34, at 7-9.

$20 \quad$ Ibid. See also Cooper $v$ Aaron, $35^{8}$ U.s. 1 (1958).

21 This term was coined by Larry Kramer. See L.D. Kramer, The People Themselves: Popular Constitutionalism and Judicial Review (New York, NY: Oxford University Press, 2004).
} 
active and ongoing sovereignty, which authorizes the political branches to speak for the people. ${ }^{22}$ In this way, they argue, popular constitutionalism can been understood to entail a stringent form of departmentalism, which is the view that each of the three branches of government possess independent and coordinate authority to interpret the Constitution. ${ }^{23}$

This article examines the development and current status of the political question doctrine theme in South African jurisprudence. It does this through a comparative discussion of the application of this doctrine in the United States. The purpose of this comparative examination is twofold: the first is to gain insight into the origins, trends and early application of the political question doctrine. The second is to gain insight into the challenges and best practices around the application of the political question doctrine in the United States. The paper argues that while the political question doctrine theme exists in South African jurisprudence, this has not matured into a clear and transparent doctrine. It impresses on the judiciary to develop a clear doctrine for South Africa. The need for this development could be illustrated by the following hypothetical.

Suppose for a moment that a citizen of South Africa brought an action seeking judicial review of the recent decision of the President of South Africa to join the BRICS Group of countries, under the theory that this decision was irrational and not in the interest of South Africans in whose name and for whose welfare the powers of government should be exercised; and that the BRICS agreement was irrational because it would not lead to a realisation of economic benefits for South Africa.

In such a challenge would the judiciary have a judicially manageable standard to determine the dispute? If not, what would be the jurisprudential justification for the Court to exercise restraint? If the judiciary were to decide to hear the dispute would it not interfere with the functioning of the executive and legislature who are constitutionally entrusted with the powers concerning foreign policy matters? Would the judiciary not be correctly accused of pronouncing on matters of policy or substituting its own notions of what is wise and politic for that of the executive or legislature? Does the power of judicial review under the Constitution authorise the judiciary to sit in judgment against the wisdom of what the legislature and executive branches do in their areas of expertise? Wouldn't the political question doctrine assist the judiciary to avoid the temptation to intrude into the terrain of the political branches

22 See R. Post and R. Siegel, 'Popular Constitutionalism, Departmentalism and Judicial Supremacy', 92 California Law Review (2004), 1027-1044.

Ibid. 
that the then Chief Justice Chaskalson warned about in Ferreira? ${ }^{24}$ These are some of the concerns that President Zuma was probably articulating in his statement quoted above.

The literature and authorities from the United States, Ghana and Uganda and perhaps other jurisdictions, suggests that the answer to the above questions is that a court would invoke the political question doctrine and abstain from determining these disputes. In South Africa, the law is uncertain and the cases that have reflected on similar questions do not provide a clear answer. It is not clear whether or when a court in South Africa would not hear a matter involving political questions with potential separation of powers implications. Notwithstanding this uncertainty, National Treasury v. Opposition to Urban Tolling Alliance (Outa) reflects a new sign of maturity in South Africa's political question doctrine jurisprudence, through its pronouncement that the duty to formulate and implement public policies lies at the heartland of executive function and domain. ${ }^{25}$ The Court in Outa observed that courts are not well suited to make decisions of that order because such decisions are constitutionally committed to coordinate political branches. ${ }^{26}$

The first part of this article discusses the history of the political question doctrine and its modern application in the United States. Part two discusses the developments and current status of the political question doctrine in South Africa. It argues that while the doctrine exists in South African jurisprudence, the Court should articulate and develop it into a coherent doctrine. It offers some suggestions in this regard and criticizes opponents of the political question doctrine in South Africa.

\section{The History of the Political Question Doctrine}

The political question doctrine was first enunciated in Marbury when it held that the separation of powers principle makes certain questions non-justiciable

\footnotetext{
24 Ferreirav Levin 1996 (1) BCLR 1 (CC).

25 Outa 2012 (6) SA 223 (CC) at para. 67.

26 Ibid. at para. 68. See also Arakaki v Lingle, 305 F.Supp.2d 1161 (2004); Corriee, supra note 8, at 980; L. Seidman, 'Secret Life of the Political Question Doctrine', 37 John Marshall Law Review (2003), 441-480, at 442-443; J.H. Choper, 'The Political Question Doctrine: Suggested Criteria', 54 Duke Law Journal (2005), 1457-1523; El-Shifa Pharmaceutical Industries v. U.s., 607 F.3d 836 (2010); Oetjen v. Central Leather Co., 246 U.s. 297 (1918); United States v. Belmont, 301 U.s. 324 (1937).
} 
because adjudicating those questions would intrude on the powers of the political branches. ${ }^{27}$ While the Marbury Court claimed the power of judicial review, it also recognized limitations on that power and said:

The province of the court is, solely, to decide on the rights of individuals, not to inquire how the executive, or executive officers, perform duties in which they have discretion. Questions in their nature political, or which are, by the constitution and laws, submitted to the executive, can never be made in this court. ${ }^{28}$

With this pronouncement, the Marbury Court instructed the judiciary to dismiss cases if the constitution's text, structure, or theory signified that an issue should be decided by an elected branch of government. ${ }^{29}$ Based on this articulation, Marbury recognized a clear difference between legal questions that the judiciary must decide and political questions they must allow the political branches to remedy. ${ }^{30}$ As Fallon has commented, Marbury not only represents the fountainhead of judicial review, but also furnishes the canonical statement of the necessary and appropriate role of the judiciary in a constitutional system founded on the principle of separation of powers. ${ }^{31}$ It is for this reason that some commentators have defended the political question doctrine on separation of powers grounds arguing that the United States Constitution is seen as assigning responsibility for interpreting or enforcing certain constitutional provisions to the elected branches of government. ${ }^{32}$

27 For a discussion of the evolution of the political question doctrine see Atlee $v$ Laird 347 F. Supp. 689, 692 (D.C.Pa.1972).

28 Marbury, supra note 6, at 170.

29 R.J. Pushaw, 'Judicial Review and the Political Question Doctrine: Reviving the Federalist "Rebuttable Presumption" Analysis', 8o North Carolina Law Review (2002), 11765-1202, at 1192-1193.

30 See S.M. Shrewsbury, 'Marbury v. Madison: the Orgins and Legacy of Judicial Review', 173 Military Law Review (2002), 160-178, at 166; and R. Price, 'Banishing the Specter of Judicial Foreign Policymaking: A Competence-Based Approach to the Political Question Doctrine', 38 New York University Journal of International Law and Politics (2006), 323-354, at 331 .

31 See R. Fallon, 'Marbury and the Constitutional Mind: A Bicentennial Essay on the Wages of Doctrinal Tension', 91 California Law Review (1993), 1-57, at 5 .

32 E. Chemerinsky, Constitutional Law (Gaithersburg, MD: Aspen Law \& Business, 2001), at p. 77; Imam et al., supra note 6; Koohi v. United States, 976 F.2d 1328 (9th Cir. 1992). 
Since Marbury, the Court has applied the political question doctrine in a number of cases. ${ }^{33}$ The case of Baker $v$ Carr $^{34}$ is perhaps the most prominent articulation of the criteria for determining what constitutes a non-justiciable political question. The case involved the question of whether an equal protection challenge to malapportionment of state legislatures is a non-justiciable political question. The Supreme Court set out what could be described as the modern articulation of the political question doctrine and ruled that a determination of whether state malapportionment of state legislatures violated the plaintiffs' equal protection rights under the United States Constitution was not a political question. ${ }^{35}$ Justice Brennan, who wrote for the majority in Baker $v$ Carr, announced six criteria for assessing when a case may be dismissed under the political question doctrine. ${ }^{36}$ These criteria are:

[1] textually demonstrable constitutional commitment of the issue to a coordinate political department; [2] or a lack of judicially discoverable and manageable standard for resolving it; [3] or the impossibility of deciding without an initial policy determination of a kind clearly for non-judicial discretion; [4] or the impossibility of a court's undertaking independent resolution without expressing lack of the respect due coordinate branches of government; [5] or an unusual need for unquestioning adherence to a political decision already made; [6] or the potentiality of embarrassment from multifarious pronouncements by various departments on one question. ${ }^{37}$

According to Brennan, the existence of one criterion is sufficient to invoke the political question doctrine. However, Brennan emphasized the limited reach of the political question doctrine so that "it is used sparingly in the context of demonstrable political question devoted to the elected branches and not simply to cases that involve political issues". ${ }^{38}$ Further, Brennan explained that

33 See Lutherv Borden, 48 U.s. 1 (1849), Colegrave v. Green, 328 U.s. 549 (1946); Grayv. Sanders, 372 U.s. 368 (1963); Reynolds v. Sims, 377 U.s. 533 (1964); Wells v. Rockefeller 394 U.s. 542 (1969).

34 Bakerv. Carr, 369 U.s. 186 (1962).

35 Ibid., at $197-198$.

36 Ibid., at 217 .

37 Ibid. See also L.H. Tribe, American Constitutional Law (New York, NY: Foundation Press, 1988), at p. 96 (discussing the different strands of the political question doctrine announced in Bakerv Carr).

38 Baker v Carr, supra note 34 at 217; see also B. Free, 'Waiting Does v Exxon Mobole Corp: Advocating the Cautious Use of Executive Opinions in Alien Tort Claims Act Litigation', 
the benefit and purpose of the political question doctrine is to preserve the separation of powers principle and minimise claims that have the potential to undermine this principle. ${ }^{39}$ Some members of the United States federal bench have suggested that the political question doctrine serves to prevent the courts from intruding unduly on certain policy choices and judgments that are constitutionally committed to the United States Congress or the executive branch. ${ }^{40}$ According to this view, a nonjusticiable political question exists when, to resolve a dispute, the court must make a policy judgment of a legislative or executive nature, rather than resolve the dispute through the application of the law. ${ }^{41}$

A further benefit of the political question doctrine is that it minimises judicial intrusion into the operations of the other branches of government and allocates decisions to the branches of government that have superior expertise in particular areas. Scharpf is an advocate of this view and has argued, for example, that the Supreme Court has rightly treated many constitutional issues concerning foreign policy to be political questions because of the greater information and expertise of the other branches of government. ${ }^{42}$ Nearly four decades ago, Bickel and Scharpf offered one of the most influential academic defences of the political question doctrine. In their commentaries, Bickel and Scharpf treat the political question doctrine as one of the devices that the judiciary utilise to define their relationship with other branches and acknowledge that courts share responsibility for interpreting the Constitution with the

12 Pacific Rim Law and Policy Journal (2003), 467-498, at 489 (arguing that the political question doctrine does not allow courts to dismiss suits merely because they address controversial political issues); Barkow, supra note 9 at 253, 262-263; A. Fickes, 'Private and Political Questions: A Critical Analysis of the Political Question Doctrine's Application to Suits Against Private Military Contractors', 82 Temple Law Review (2009), 525-560, at 531 (noting that the judiciary can hear politically charged cases without invoking the political question doctrine); S. Willig, 'Politics As Usual? The Political Question Doctrine in Holocaust Litigation', 32 Cardozo Law Review (2010-2011), 723-753, at 732 (noting that not every case which touches on foreign policy is nonjusticiable); C.R. Chase, 'The Political Question Doctrine: Preventing the Challenge of us Foreign Policy in 767 Third Avenue Associates v Consulate General of Socialist Federal Republic of Yugoslavia', 5o Catholic University Law Review (2001), 1045-1079, at 1055 (observing that the political question doctrine does not prevent a court from hearing a case simply because it involves a political issue).

39 Ibid. See also Lane v. Halliburton, $5_{29}$ F.3d 548 (2008).

$40 \quad$ Koohi v. United States, 976 F.2d 1328 (9th Cir. 1992).

41 E.E.o.c. v. Peabody W. Coal, 400 F. 3 d 774 (9th Cir. 2005).

42 Scharpf, supra note 6 at $567,5^{8} 3^{-} 5^{84}$. 
other branches of government. ${ }^{43}$ According to Bickel and Scharpf, entangling the judiciary with the other institutions of the political system in ways that would not benefit the nation is imprudent. ${ }^{44}$ For Bickel and Scharpf, the political question doctrine provides the judiciary with techniques for refraining from deciding cases on the merits when doing so would be unwise. ${ }^{45}$

Since Bakerv Carr was decided, the Supreme Court has dismissed cases on the basis of the political question doctrine. The first notable case was Gillian $v$ Morgan, ${ }^{46}$ where it held that courts should not examine the training of the Ohio National Guard because doing so would invade critical areas of responsibility vested by the United States Constitution in the legislative and executive branches of government. ${ }^{47}$ In a second case, Nixon $v$ United States, ${ }^{48}$ the Supreme Court held that the impeachment of a judge was a non-justiciable political question..$^{49}$ Despite the fact that the Supreme Court has not invoked the political question doctrine in recent years, federal cases in the United States reveal that lower courts frequently apply the doctrine in adjudication of constitutional cases. ${ }^{50}$ Based on the analysis of these federal cases, it could be argued that the discourse around the political question doctrine among judges and academics has centered on ensuring a consistent application of the doctrine. ${ }^{51}$ While inconsistent application of any legal principle is not desirable, it can be expected in the development and application of a complex concept like

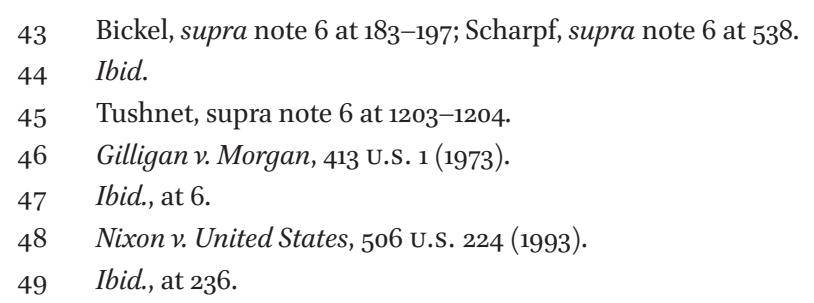

$5^{0}$ See Mulhern, supra note 6 at 106 (noting that the political question doctrine is more prominent in the opinions of the lower federal courts). For some of the cases that demonstrate this frequent application and trends of the political question doctrine, see, Gonzales-Vera $v$ Kissinger 449 F.3d 126o (2006); Schneider v Kissinger, 412 F.3d 190 (2005) (emphasizing that the political question doctrine does not leave executive power unchecked because political branches effectively exercise checks and balances on each other in the area of political questions); Corriee, supra note 8 at 982-984 (reasoned that allowing this action to proceed would necessarily require the judiciary to question the political branch's decision to grant extensive military aid to Israel); and Schroeder v Bush, 263 F.3d 1169 (2001).

51 See M. Finkelstein, 'Judicial Self-Limitation', 37 Harvard Law Review (1924), 338-364, at 344-345; and Redish, supra note 3 at 1031-1032 (arguing that academic debate on the political question doctrine has centred over the principled use of the doctrine; and that the doctrine is very much alive in Supreme Court decisions). 
the political question doctrine. ${ }^{52}$ Courts always disagree and at times become unclear in the development and application of a significant number of legal principles but this does not entail those principles at issue are discredited or be abandoned..$^{53}$ Due to its prominence, the political question doctrine has become a relevant topic in South Africa.

\section{The Application of the Political Question Doctrine in South Africa}

\subsection{Introduction}

South Africa went through constitutional changes in the early $1990{ }^{54}$ These changes, negotiated at the Convention for a Democratic South Africa (CODESA), culminated in the adoption of the Interim Constitution of 1993. As explained earlier, one of the most notable changes introduced by the Interim Constitution was the declaration of the supremacy of the Constitution and that any law or act in conflict with it had no force and effect. ${ }^{55}$ One of the political compromises reached at CODESA was that the Interim Constitution would govern South Africa for an interim period until the Constitution of 1996 was adopted and certified by an independent body, being the Court. ${ }^{56}$ According to Currie and De Waal, central to the implementation of the Interim Constitution was the establishment of a Court to give effect to the supremacy of the Constitution and the bill of rights. ${ }^{57}$ Further, Currie and De Waal observe that "the idea of establishing and requiring the Court to certify the Constitution was motivated by, among other things, fears amongst liberation movements that some of the old judges would use their judicial powers to undermine the newly created democratic order". 58 The above compromise was encapsulated in section 71 of the Interim Constitution and it provided as follows:

$5^{2}$ See Finkelstein, supra note 51, at 344-345; Redish, supra note 3 at 1033; Jaffe, supra note 11 at 1043-1063 (discussing recent cases applying the political question doctrine).

53 See Rautenbach, supra note 1, at 28 (suggesting that the political question doctrine should not be adopted in South Africa because it is highly controversial in its land of origin).

54 For a discussion of the transition to a democratic state, see H. Klug, Constituting Democracy: Law, Globalism and South Africa's Political Reconstruction (Cambridge: Cambridge University Press, 2000).

55 Section 4 of the Interim Constitution 1993.

56 Currie and De Waal, supra note 13, at 64-65.

57 Ibid., at 65 .

58 Ibid., at 274 . 
71 Constitutional Principles and certification

(1) A new constitutional text shall -

(a) comply with the Constitutional Principles contained in Schedule 4; and

(b) be passed by the Constitutional Assembly in accordance with this Chapter.

(2) The new constitutional text passed by the Constitutional Assembly, or any provision thereof, shall not be of any force and effect unless the Court has certified that all the provisions of such text comply with the Constitutional Principles referred to in subsection (1) (a).

(3) A decision of the Court in terms of subsection (2) certifying that the provisions of the new constitutional text comply with the Constitutional Principles, shall be final and binding, and no court of law shall have jurisdiction to enquire into or pronounce upon the validity of such text or any provision thereof....

Thirty four principles were agreed upon at CODESA to inform the drafting of the Constitution. Two of these principles are most relevant for our purposes, and provided as follows:

IV. The Constitution shall be the supreme law of the land. It shall be binding on all organs of state at all levels of government

VI. There shall be a separation of powers between the legislature, executive and judiciary, with appropriate checks and balances to ensure accountability, responsiveness and openness.

Pursuant to section 71 of the Interim Constitution, the Court eventually certified the Constitution in 1996 after it was adopted by Parliament sitting as the Constitutional Assembly.

\subsection{The Emergence of the Political Question Doctrine in South Africa}

During the reign of the Interim Constitution, the Court in Ferreir ${ }^{59}$ had to determine the constitutionality of section $417(2)$ (b) of the Companies Act 61 of 1973. The latter provision provided that any person summoned for an examination into the affairs of a company may be required to answer questions, and notwithstanding that the answer to such questions might incriminate him, any answer could be used in evidence against him. The Court ruled that section $417(2)(b)$ was in conflict with the right to freedom and security of a person,

Ferreira, supra note 24 . 
which included the right not to be detained without trial in section 11(1) of the Interim Constitution. In his concurring opinion, Chief Justice Chaskalson used this case to explain what he thought is the constitutionally envisaged relationship between the judiciary and the political branches of government in connection to the determination of political questions under the new democratic order. He pronounced that:

Implicit in the social welfare state is the acceptance of regulation and redistribution in the public interest. Whether or not there should be regulation and redistribution is essentially a political question which falls within the domain of the legislature and not the court. It is not for the courts to approve or disapprove of such policies. What the courts must ensure is that the implementation of any political decision to undertake such policies conforms with the Constitution. It should not, however, require the legislature to show that they are necessary if the Constitution does not specifically require that this be done. ${ }^{60}$

Chaskalson made the above remark in support of his view against a broad interpretation of section 11(1) of the Interim Constitution. He cautioned against falling into the pitfall of Lochner $v$ New York, ${ }^{61}$ which gave rise to serious questions about judicial review and the relationship between the judiciary and the elected branches of government in the United States. In his view, section 11 should not be construed so broadly that "we overshoot the mark and trespass upon the terrain that is not rightly ours". ${ }^{62} \mathrm{He}$ further explained that in a democratic society the role of the legislature, as a body reflecting the dominant opinion, should be acknowledged. He emphasised the need to bear in mind that there are functions that are properly the concern of the political branches; that while these functions may overlap, the terrains are separate and should be kept separate. ${ }^{63}$

Regarding the determination of political questions, Chaskalson's pronouncement above should be understood in light of what Justice Kpegah said in the Ghanaian case of Amidu v President Kufuor. ${ }^{64}$ There, Kpegah said that

\footnotetext{
60 Ibid., at 105 .

61 Lochner $v$ New York, 198 U.s. 45 (1905). For a discussion of what has been termed as the Lochner era, see B. Wright, The Growth of American Constitutional Law (New York, NY: Houghton-Mifflin, 1942), at p. 154.

62 Ferreira, supra note 24, at 106.

63 Ibid.

64 Amiduv President Kufuor (2001-2002) SCGLR 138.
} 
"the intrinsic proposition in the Constitution is that the policy which should inform any legislation are matters for the political branches to decide". 65 Like Kpegah, Chaskalson considers those policy choices to be of no concern to the judiciary and notes that it is not for the judiciary to approve or disapprove such policy choices. ${ }^{66}$ In his pronouncement, Chaskalson's suggestion is that the Constitution bars the judiciary from requiring the political branches of government to demonstrate the necessity under the Constitution for the policy choices that inform legislative acts because, in his view, the political branches have discretion in this regard. In other words, the suggestion by Chaskalson, as Redish has agreeably argued elsewhere in the American context, is that when a Constitution is silent concerning the need for legislation in a particular area, a Constitution should be understood as granting the political branches discretion to formulate new policies in those areas without judicial interference. ${ }^{67}$ Justice Ngcobo makes a similar suggestion in Doctors for Life and says 'when a constitutional obligation requires a political branch of government to determine in the first place what it necessary to fulfil its obligation by leaving to the political branch to determine what is required of it in this regard, a review by a court on whether the obligation has been fulfilled intrudes the separation of powers principle. ${ }^{68}$ Ngcobo suggests 'that political branches have discretion to determine how to fulfil the obligation in such circumstances. ${ }^{69}$

Evidently, Chaskalson would probably agree that the determination of whether regulation 28 of the Pension Funds Act 24 of 1956, which regulates the investment of private pension funds in South Africa, should exist or is necessary under the Constitution is a political question and the judiciary may not approve or disapprove the outcome of that question. These views by Chaskalson and Ngcobo, which recognise the limits of judicial power in determining political questions, were confirmed by the Court during the certification of the Constitution.

The certification process was the first time the Court had the occasion to interpret the Constitution before it became enforceable. In First Certification Judgement, the Court described its functions and powers in the certification process (which are not different from its ordinary powers and functions) as follows:

65 Ibid., at 154 .

66 Ferreira, supra note 24, at 105.

67 Redish, supra note 3, at 5-10.

68 Doctors for Life International v Speaker 2006 (12) 1399, at p. 1415.

69 Ibid. 
First and foremost it must be emphasised that the Court has a judicial and not a political mandate. Its function is to certify whether all the provisions of the new text comply with the constitutional principles. That is a judicial function, a legal exercise. Admittedly a constitution, by its very nature, deals with the extent, limitations and exercise of political power as also with the relationship between political entities and with the relationship between the state and persons. But this Court has no power, no mandate and no right to express any view on the political choices made by the constitutional assembly in drafting the new text, save to the extent that such choices may be relevant either to compliance or non-compliance with the constitutional principles. Subject to that qualification, the wisdom or otherwise of any provision of the new text is not this Court's business. $^{70}$

It is my submission that the above statements of law in Ferreira and the First Certification Judgment are local authorities for the application of the political question doctrine theme in South Africa. To this extent, these statements of the law can be equated with the famous authoritative words from Marbury, ${ }^{71}$ Tuffuor v Attorney General ${ }^{72}$ Onuoha $v$ Okafor, ${ }^{73}$ and Matovu, ${ }^{74}$ as authorities for political question doctrine in the United States Ghana, Nigeria and Uganda, respectively.

Clearly, even before the First Certification Judgment, Chaskalson, motivated by separation of powers concerns, was apprehensive about the judiciary not overreaching to determine political questions that were the preserve of the political branches in the new South Africa. It is apparent from Chaskalson's pronouncements that certain political questions are not appropriate for determination by the courts. In my view, these pronouncements by the Court in Ferreira and the First Certification Judgment can only be explained in the context of the political question doctrine. In fact, Chaskalson's views in Ferreira are indistinguishable from those articulated by Justice Acquah in Mensah. ${ }^{75} \mathrm{In}$

\footnotetext{
$70 \quad$ In re: Certification of the Constitution of the Republic of South Africa, 19961996 (10) BCLR 1253, 1273 (CC).

71 Marbury, supra note 6, at 170.

72 Tuffuor v Attorney General [1980] GLR 637, at 651-652, read together with Ghana Bar Association, supra note 6.

73 Ouohav Okafor (1983) NSCC 494, at 507.

74 Uganda v. Commissioner of Prisons Ex Parte Matovu, [1966] EALR 531 (holding that "the government's exposition of political question doctrine as elaborated in Luther $v$ Borden, 48 U.S. 1 (1849) cannot be faulted).

JH Mensah v Attorney-General [1996-1997] SCG LR 320.
} 
that case, Acquah expressed some reservations about the political question doctrine. He saw one potential interpretation of the doctrine, which could be perceived as granting political immunity for violations of the Constitution by the elected branches of government. In turn, he offered his preferred understanding of the doctrine which, in his view, complies with Ghana's constitutional design. I call his preferred version the "compromised political question doctrine". He said:

If by the political question doctrine, it is meant that where the Constitution allocates power or function to an authority, and that authority exercises that power with the parameters of that provision and the Constitution as a whole, a court has no jurisdiction to interfere with the exercise of that function, then I entirely agree that the doctrine applies in our constitutional jurisprudence. But if by the doctrine, it is meant that even when the authority exercises that power in violation of the constitutional provision, a court has no jurisdiction to interfere because it is the Constitution which allocated that power to that authority, then I emphatically disagree. ${ }^{76}$

Seedorf and Sibanda have made a similar observation in the South African context and said:

Like courts in other jurisdictions, the Court has on frequent occasions employed the idea of judicial restraint, a conscious decision based on separation of powers concerns not to interfere with decisions by the other branches of government, provided that they are in line with the Constitution. ${ }^{77}$

In subsequent cases decided after the Constitution of 1996, the Court has consistently expressed similar views concerning the role of the judiciary in adjudicating certain political questions.

\subsection{Political Question Doctrine or Judicial Restraint:Jurisprudence from the Constitutional Court}

Emerging jurisprudence has pointed to the reluctance of the Court to adjudicate political questions. It is not clear from this jurisprudence whether the Court is merely exercising deference to the other branches of government or

$76 \quad$ Ibid., at 368 .

77 Seedorf and Sibanda, supra note 6, at $12-56$. 
applying a political question doctrine. One of the cases that illustrate this irony is $U D M .{ }^{78}$ In $U D M$, the Court upheld three Acts of Parliament that allowed members of Parliament to cross the floor in Parliament without losing their seats. It struck down the Loss or Retention of Membership of National and Provincial Legislatures Act 22 of 2002, which had been tabled together with the other three Acts. In describing the issue before it, the Court explained that:

This case is not about the merits or demerits of the provisions of the disputed legislation. That is a political question and is of no concern to this Court. What has to be decided is not whether the disputed provisions are appropriate or inappropriate, but whether they are constitutional or unconstitutional. It ought not to have been necessary to say this for that is true of all cases that come before this Court. We do so only because of some of the submissions made to us in argument, and the tenor of the public debate concerning the case which has taken place both before and since the hearing of the matter. ${ }^{79}$

While the current position is that parliamentarians cannot cross the floor in Parliament without losing their seats, the outcome in the UDM signaled the need for the Court to give absolute deference to the elected branches of government in cases involving alleged violations of constitutional provisions that are assigned to the legislative branch of government to resolve..$^{80}$ It is interesting to note that while $U D M$ was widely criticized by commentators, ${ }^{81}$ none of the criticisms is developed around the Court's acknowledgement and expression of the political question doctrine sentiments above. What is evident from UDM is that the Court is silent on what kind of political questions it will not entertain.

Another significant case, which demonstrates the reluctance of the Court to determine political questions, is Kaunda. ${ }^{82}$ That case involved the question of whether the applicants (who were South African citizens) were entitled to diplomatic protection under the Constitution and international law, when they were arrested on criminal charges in Zimbabwe. The Court ruled they were not, and explained that while it had jurisdiction to decide matters involving diplomatic protection, courts could not tell the executive how to make

\footnotetext{
78 UDM $v$ President of South Africa 2002 (11) BCLR 1179.

79 Ibid., at 1184.

8o See Constitution Fourteenth Amendment Act of 2008, General Notice 31791.

81 See G. Devenish, 'Political musical chairs - the saga of floor-crossing and the Constitution', 15 Stellenbosch Law Review (2004), 52-65, at 64.

$82 \quad$ Kaunda $v$ President of the RSA 2004 (1) BCLR 1009 (CC).
} 
diplomatic interventions for the protection of its nationals. ${ }^{83}$ In her dissenting opinion, Justice O'Regan offered the following rationale:

It is clear that under our Constitution the conduct of foreign affairs is primarily the responsibility of the executive, the arm of government best placed to conduct foreign affairs. It is clear from the existing jurisprudence of this Court that all exercise of public power is to some extent justiciable under our Constitution, but the precise scope of the justiciability will depend on a range of factors including the nature of the power being exercised. Given that the duty to provide diplomatic protection can only be fulfilled by government in the conduct of foreign relations, the executive must be afforded considerable latitude to determine how best the duty should be carried out. [In] any proceedings ... a court will bear in mind that foreign relations is a sphere of government reserved by our Constitution for the executive and it will accordingly be careful not to attribute to itself superior wisdom in relation to it. ${ }^{84}$

Short of articulating a clear political question doctrine in Kaunda, the majority of the Court concluded that decisions made by the government in foreign affairs are subject to constitutional control. ${ }^{85}$ It held that courts required to deal with such matters will, however, give particular weight to the government's special responsibility for and particular expertise in foreign affairs and the wide discretion that it must have in determining how best to deal with such matters. ${ }^{86}$ It is interesting to note that the Court does not recognize the possibility of granting absolute deference to elected branches on those foreign affairs questions even though it recognizes the inability for courts to determine the matters for lack of expertise.

In this regard, the Court misses the point that the political question doctrine requires more than mere deference in determining matters that are committed to the political branches of government to resolve. It is clear that the Court is mindful of the potential limits of its own power and the separation of powers concerns in determining foreign affairs. However, Kaunda fails to adequately

\footnotetext{
83 Ibid., at 1029 .

84 Ibid., at 107-1074.

85 Ibid., at 1045 .

86 Ibid. See Tushnet, supra note 6, at 1232 (advocating that the judiciary should be restrained from resolving issues that other branches are better suited to resolve such as foreign affairs); Free, supra note 39; Scharpf, supra note 6 , at $567,583^{-584}$ (agreeing with the approach of treating foreign affairs questions as political questions).
} 
define the boundaries of discretion afforded to the executive or the jurisprudential justification for such discretion. While Kaunda was clear that executive action was subject to constitutional control, presumably as part of the necessary checks and balances, it is silent concerning the limits on the judiciary. In other words, Kaunda did not specifically consider or apply the political question doctrine, which operates as a limitation on judicial powers even though it decided the case based on political question doctrine sentiments. ${ }^{87}$ What the Court did was to provide some foundation for a potential development or application of the doctrine in future cases. The closest it got to articulating a political question doctrine is when Justice O'Regan in the quote above spoke of the extent to which the exercise of public power is justiciable, but failed to take this discussion to its logical conclusion by developing a clear political question doctrine. It is this double speak that you encounter in UDM, Kaunda and other cases that makes the case for the Court to develop a clear political question doctrine that would bring certainty in the law. In this regard, I welcome the proposition by Asare's that courts must justify when they invoke the political question doctrine because it forces them to clarify the doctrine and its application. ${ }^{88}$ South African courts have not done this in those cases where they have made statements that can only be read as expressions of the political question doctrine. ${ }^{89}$

Perhaps, the most recent expression of the political question doctrine theme can be found in Outa..$^{90}$ This case was a direct appeal to the Court from a high court decision granting a temporary restraining order against several government departments to prevent them from implementing the Gauteng Freeway Improvement Project (GFIP). A major component of this implementation was a policy decision taken by the executive branch that the expenditure related to the GFIP would be funded by tolling the roads on a user pay principle. The Court was seized to determine whether the high court was correct in granting the restraining order. It held that the high court did not take

87 See, for example, Chase, supra note 38 (arguing that the political question doctrine limits judicial power); Endicott, supra note 2, at 538 (arguing that the political question doctrine represents the judicial effort to ensure that courts do not hamper the functioning of the political branches of government); U.s. Department of Commerce v. Montana, 503 U.s. 442, 458 (1992); Bakerv. Carr, supra note 34, at 217-218.

88 S.K. Asare, Can the Political Doctrine Question Save MP Amoeteng, 16 November 2006, available online at http://www.ghanaweb.com/GhanaHomePage/NewsArchive/artikel .php?id=113967.

89 See Mazibuko, supra note 6 (where based on separation of powers concerns the judge Davis refused to intervene in a matter involving political questions). Outa, supra note 25 . 
sufficient consideration of separation of powers concerns when it granted the order. It reasoned that the duty of determining how public resources are to be used is committed to the executive and legislative arms of government, and that courts must refrain from entering the exclusive terrain of the other arms of government unless intrusion is mandated by the Constitution itself. ${ }^{91}$ In this case, it was not, and the restraining order granted by the high court was set aside. Commenting on the Court decision in Outa, one commentator has argued that "this is unquestionably the most important judgment because it shows that the judiciary is acutely conscious of not interfering in core areas of legislative and executive competence". ${ }^{92}$

\subsection{Foreign Affairs As Non-justiciable Questions: A High Court Perspective}

In an earlier case of Kolbatschenko, ${ }^{93}$ the high court considered and determined what Okpaluba calls the American version of the political question doctrine to resolve a dispute involving foreign affairs. ${ }^{94}$ I will point out later that there is no such thing as the American version of the political question doctrine because that doctrine emerges from any constitutional system underpinned by the principle of separation of powers. In Kolbatschenko, the second respondent was granted permission by means of a court order to request assistance from a foreign state in obtaining information for use in an investigation into an alleged offence. This permission was granted pursuant to section 2 of the International Cooperation in Criminal Matters Act 75 of 1996 (ICCMA). Also at issue was a letter of request to the government of Liechtenstein for assistance in obtaining certain information relating to three entities with which the applicant had nefarious links. ${ }^{95}$ The letter of request was acted upon by the Liechtenstein government, which led the applicant to apply to rescind the order granted by the court.

The second respondent defended the application on two grounds. The first was that the application involved political questions which were non-justiciable;

$91 \quad$ Ibid., at paras 44,67 .

92 Serjeant at the Bar, E-tolling case an opportunity for Concourt to define its ambit, Mail and Guardian 34 (Friday 28 September 2012), available online at http://mg.co.za/article/ 2012-09-28-oo-e-tolling-case-an-opportunity-for-concourt-to-define-its-ambit(last visited October 4, 2012).

93 Kolbatchenko $v$ King [2001] 4 All SA 107 (C).

94 See Okpaluba, supra note 6 at $33^{1}$ (discussing that Kolbatchenko stands for the proposition that there are issues of foreign affairs, which are non-justicable since courts have no judicial standards by which to judge them).

$95 \quad$ Kolbatchenko, supra note 93, at 111. 
that certain disputes are non-justiciable in that the nature and subject matter are not susceptible to the judicial process. ${ }^{96}$ This argument was enhanced by the wording of section 34 of the Constitution, which provides that:

everyone has the right to have any dispute that can be resolved by the application of law decided in a fair public hearing before a court or, where appropriate, another independent and impartial tribunal or forum.

Based on the above provision, the second respondent submitted that a dispute may be regarded as non-justiciable if it cannot be resolved by the application of the law or other legal norms; ${ }^{97}$ that many acts in the realm of foreign affairs are not governed by legal norms but involve the consideration of polycentric social, economic and political interests. As such, courts should exercise restraint because of the lack of judicially manageable standards by which to judge such issues. ${ }^{98}$ It is important to note that the second respondent's argument was developed from the six factors articulated by Brennan in Baker v Carr. ${ }^{99}$ The high court dismissed this argument, a point I will come back to later.

An argument similar to the one in Kolbatschenko was advanced in Outa. However, unlike in Kolbatschenko, the argument was raised in Outa to achieve the opposite result, namely to prevent the application of the political question doctrine in the case. The respondents in Outa argued that the policy decision of government to implement the GFIP was not so political, economic or policy laden to warrant judicial deference (or in my words the application of the political question doctrine); that the "impugned decision is not of the executive and polycentric character as in UDM and other cases". ${ }^{100}$ At the heart of this argument is an acknowledgement by the respondent that had the case involved certain types of political or policy laden questions, the Court would be expected to abstain from adjudicating the matter. The Court rejected the

$96 \quad$ Ibid., at 120.

97 Ibid.

98 Many academic commentaries agree with this view. See Free, supra note 39 (arguing that the political question doctrine enjoys special potency in foreign affairs); Scharpf, supra note 6 (agreeing with the Supreme Court's approach of treating foreign affairs questions as political questions); G. Noyes, 'Cutting the President Off From Tin Cup Diplomacy', 24 University of California Davis Law Review (1991), 841-878, at 864.

99 Bakerv Carr, supra note 34, at 217.

100 Outa, supra note 25, at para. 39, citing Glenister v President of the RSA 2009 (2) BCLR 136 (CC) and International Trade Administration Commission v SCAW South Africa 2010 (5) BCLR 457 (CC). 
respondent's argument because it found that the impugned decision was political or policy laden in nature, and hence was outside the scrutiny of the courts because of separation of powers concerns. ${ }^{101}$

The second ground of defence by the second respondent in Kolbatschenko was that the request for international assistance was a political act in the realm of foreign affairs and thus non-justiciable. To support this argument, the second respondent relied on some South African authorities where courts had refused to evaluate decisions in the realm of foreign affairs involving issues of high executive nature. ${ }^{102}$

In dismissing this argument, the high court observed that the decision to request international assistance did not involve the evaluation of social and economic policy among competing claims. Rather, it implicated legal questions such as the interpretation of the ICCMA and the requirements for judicial review of administrative decision making encapsulated in the Constitution and case law. ${ }^{103}$ Further, the high court rejected the view that the case involved matters of high executive nature directly impacting upon the relationship between South Africa and a foreign state. ${ }^{104}$ Instead, it reasoned that the case involved the relationship between South Africa and an individual, the applicant, as a person who is suspected of having committed various offences in South Africa. In addition, the high court dismissed the argument developed from Baker $v$ Carr that in assessing the legality of the requests, it (the high court) would lack judicially manageable standard by which to judge the issues involved. It found that the subject-matter of the case was justiciable.

Despite the outcome in Kolbatchenko, it seems from the arguments and holding that the high court accepted the political question doctrine as applicable to constitutional adjudication in South Africa but found it inapplicable to the facts of the case. In other words, while rejecting the application of the political question doctrine, the high court in Kolbatchenko can be credited with founding the basis for a potential application of the political question doctrine in a future case. Nevertheless, there are problems with the case law development involving political questions in South Africa, which I now turn to.

\footnotetext{
101 Outa, supra note 25, at para. 39.

102 Ibid., at 123-124.

103 Ibid.

104 Chase, supra note 38 , at 1046 (arguing that the recognition of a foreign state or nation is a political question committed to the political branches of government).
} 


\subsection{Challenges to the Implementation of the Political Question Doctrine in South Africa}

There are two main challenges with the current implementation of the political question doctrine theme. Firstly, the case law developments demonstrate that an immature political question doctrine exists in South Africa. Just as Cowper and Sossin have observed in the Canadian context, in South Africa the political question doctrine theme has been advanced and considered, but in a gradual manner without being recognised as an element of a lucid doctrine. ${ }^{105}$ There are a number of cases in which South African courts have acknowledged the necessity of abstaining from deciding certain political questions. ${ }^{106}$ What is missing is a clearly stated and acceptable principle to guide the courts when similar questions arise in the future. Seedorf and Sibanda agree with this assessment in their study of separation of powers and the political question doctrine in South Africa. ${ }^{107}$ While reflecting on the opinion of Chaskalson in Ferreira, they argue that the Court has followed the United States model in so far as it has accepted that its power to decide a case may be limited by a lack of judicially discoverable and manageable standards. ${ }^{108}$ Further, they argue that the case law also validates the view that there are some questions which courts cannot decide, such as political or moral questions, but has not abstained from deciding these questions as would be the case in other jurisdiction. ${ }^{109}$ Seedorf and Sibanda observe that while the "Court has on a frequent occasions recognized the political question doctrine without calling it such, it is necessary that the courts themselves formulate, articulate and apply principles for guiding the limits of their own powers and prevent their abuse". ${ }^{110}$

In the main, Seedorf and Sibanda accept that while some elements of the political question doctrine exist in South African jurisprudence, there is a need for the development of clear doctrine. I share the views of Seedorf and Sibanda that the problem is with the courts, which have not clearly articulated the political question doctrine and its purpose. It is not clear from the case law whether and when the courts will hear or dismiss a matter involving political questions, and what jurisprudential justifications can be offered. Okpaluba

\footnotetext{
105 G. Cowper and L. Sossin, 'Does Canada Need A Political Questions Doctrine?', 16 Supreme Court Law Review (2002), 343-372, at 347.

106 Kaunda, supra note 82; Ferreira supra note 6; Mazibuko v Sisulu, supra note 6; UDM v. President of the RSA, supra note 78; Outa, supra note 25.

107 Seedorf and Sibanda, supra note 6, at ${ }^{12-52}$.

108 Ibid., at $12-53$.

109 Ibid., at $12-52$.

110 Ibid., at $12-56$.
} 
also believes in the benefits of developing a clear political question doctrine for South Africa. He has suggested that for a matter raising a purely political question to emerge, it must be clear that judicial intervention lacks constitutional foundation,"11 and that "that is a political question over which a court cannot assume jurisdiction, entertain its cause of complaint or grant any relief in any exercise of judicial authority. ${ }^{112}$ He concludes that "such a matter, whether it is expressed in the language of the political question doctrine of American vintage, or simply dismissed for being unamenable to the judicial process as the common law courts would put it, is non-justiciable in a South African court as it is in the courts of the United States, Australia, Canada, England and Nigeria". ${ }^{113}$

Secondly, while the courts, particularly the Court, have recognised in a number of cases the limits of judicial power in general and in relation to the adjudication of political questions, they have failed to explain this in the context of the political question doctrine, which is founded upon the principle of separation of powers. Although the political question doctrine was not the substance of the case, Ngcobo in Doctors for Life ${ }^{114}$ identified an important characteristic of the political question doctrine that is missing in South African case law, which can be used to develop the doctrine in South Africa and said:

courts must be conscious of the vital limits on judicial authority and the Constitution's design to leave certain matters to other branches of government. They too must observe the constitutional limits of their authority. This means that the judiciary should not interfere in the processes of other branches of government unless to do so is mandated by the Constitution. ${ }^{115}$

The Court has failed to link separation of powers concerns, similar to the ones identified by Ngcobo above, with the limits on judicial powers, particularly in relation to political questions committed to other branches of government. Consequently, this has led to the failure of the Court to develop a clear political question doctrine that would be used to dispose of such questions in the future. There is a disjuncture between the Court's rationale and recognition of its limits in the adjudication of certain political questions in the above cases with the principle of separation of powers. The effect of the political question

\footnotetext{
111 Okpaluba, supra note 6, at 331.

112 Ibid.

113 Okpaluba, supra note 6, at 131 .

114 Doctors for Life, supra note 84, at 1417.

115 Ibid., at $1417-1418$.
} 
doctrine is that it prevents a court from hearing a matter due to separation of powers concerns. ${ }^{116}$ However, what the case law in South Africa shows is that courts recognise certain political questions in cases and the limits of the courts' power to deal with those questions but at the same time take a flexible approach, as Seedorf and Sibanda observed, and proceed to adjudicate those cases instead of leaving them to be resolved in the political process. ${ }^{117}$ This is a major challenge to the development and implementation of the political question doctrine in South Africa. Nevertheless, in his concurring opinion in Outa, Justice Froneman favours a move towards full application of the political question doctrine (without calling it such) when he declared that "courts should not determine what kind of funding should be employed for infrastructure project and who should bear the brunt for that cost."118 He correctly observes that the remedy against such policy or political decisions lies in the political process. ${ }^{119}$

\subsection{The Limits of the Political Question Doctrine in South Africa}

It is important to mention that the application of the political question doctrine does not entail that every political question is immune from judicial review. ${ }^{120}$ Courts that have applied this doctrine expressly recognise the limits of its reach, and apply it only in those cases that have the potential to jurisprudentially preserve the concept of separation of powers and where the Constitution has committed the determination of a question to another branch of government. ${ }^{121}$ In Baker $v$ Carr, the case that has influenced the application of the political question doctrine in many countries, Brennan makes it evident that the doctrine should be applied cautiously to political questions committed to the elected branches and not simply cases that concern political questions. ${ }^{122}$ His Ghanaian counterpart, Kpegah in Ghana Bar Association subscribes to this

116 See US Department of Commerce v Montana, 503 U.s. 442 (1992) at 458 (noting that the political question doctrine restrains judicial authority); Chase, supra note 39 (noting that political question doctrine limits judicial authority).

117 See Endicott, supra note 2, at 538.

118 Outa, supra note 25, at para. 95.

119 Ibid. See also Chief Enyi Abaribe v. Speaker Abia State House of Assembly (2003) 14 NWLR (pt788) 466 (explaining that "in cases involving political questions appeal for relief does not belong here. Appeal must be to an informed, civically militant electorate").

120 See Immigration and Naturalization Serv. v. Chadha, 462 U.S. 919 (1982) (stating that the presence of constitutional issues with significant political overtones does not automatically invoke the political question doctrine); and Chase, supra note 39 at 1055 .

121 See Wechsler, supra note 3 , at $7-8$.

122 Bakerv Carr, supra note 34, at 217. 
view and recognises the limited reach of the doctrine when he observed that "it is legitimate to say that the mere fact that a suit seeks the protection of a political right does not mean that it presents a political question and therefore non-justiciable". ${ }^{123}$ Furthermore, Unganda's Justice Kanyeihamba in Tinyefuza subscribes to this view and argues that courts should avoid adjudicating upon political questions unless in very clear cases of violation or threatened violations of individual liberty are shown. ${ }^{124}$ In the South African context these limitations will have to be recognised in the development and application of a clear doctrine for South Africa. This is important in light of what the Court has said about the political consequences of its functions. ${ }^{125}$

In Doctors for Life, Ngcobo made an important observation that 'it was envisaged that this [Court] would be called upon to adjudicate finally in respect of issues which could inevitably have important political consequences. Consistent with this role, he noted, section 167(4) confers exclusive jurisdiction on the Court in a number of crucial political areas. The 'purpose of giving this Court exclusive jurisdiction to decide issues that have important political consequences is to preserve the comity between the judicial branch of government and the other branches of government by ensuring that only the highest Court in constitutional matters intrudes into the domain of other branches of government. ${ }^{126}$ Recognizing the political consequences of a broad construction of section 167(4), Ngcobo held that the section should be given a narrow meaning. 127

Thus, if anything is to be learned from the application of the political question doctrine in other countries is that the doctrine is not absolute in its application because it only applies where the Constitution commits a question to other branches of government. ${ }^{128}$ Courts will inevitably adjudicate cases that

\section{Ghana Bar Association, supra note 76 , at 265.}

124 Tinyefuza, supra note 6, at 12.

125 See President of the RSA v SARFU, 1999 (7) BCLR 725, 762-763 (CC) (explaining that "one of the functions of the Constitutional Court is to exercise exclusive jurisdiction in a number of crucial political areas in respect of issues which would inevitably have important political consequences"). Similarly, the Supreme Court of Appeal has ruled that the 'invalidation of an Act of Parliament for breach of the constitutional duty to facilitate public involvement in its processes would be pre-eminently a crucial political question, which the Constitution reserved for the Constitutional Court to decide. See King v Attorneys Fidelity Fund Board of Control, 2006 (4) BCLR 462 (SCA).

126 Doctors For Life, at 1403.

127 Ibid.

128 See V. Pappalardo, 'Isolationism or Deference? The Alien Tort Claims Act and the Separation of Powers', 10 Michigan Journal of International Law (1989), 886-911, at 901; 
have political implications and may even be required to give some deference to the political branches, but these cases must be distinguished from those cases involving political questions in which absolute deference is required. ${ }^{129}$

\subsection{Justifying the Necessity of a Political Question Doctrine in South Africa}

What needs to happen in South Africa is for the courts to clearly articulate the political question doctrine and clarify when it applies and how. ${ }^{130}$ The body of case law from Ghana, Nigeria, Uganda and United States are valuable as examples of how other judiciaries have come to constrain judicial reactions to political questions. That case law demonstrates the notion that old and recent constitutional democracies have jurisprudentially defined and developed, within their constitutional histories and designs, some constitutional mechanism for dealing with political questions that threaten or implicate the equilibrium of power among the three arms of government. South Africa is lacking behind in this regard and in my view the Court should, in a future case, consider adopting some aspects of the six factors in Baker $v$ Carr. Any blanket rejection of the political question doctrine, as Kpegah warned in the context of Ghana, will create jurisdictional and separation of powers problems for South Africa in the future. ${ }^{131}$ I say this for two reasons.

Firstly, because I agree with the caution recently made by Davis in Mazibuko about the threat to judicial independence when the judiciary is drawn in to resolve political questions that are beyond its competence or jurisdiction. Davis said the following:

An overreach of the powers of judges, their intrusion into issues which are beyond their competence or intended jurisdiction or which have been deliberately and carefully constructed legally so as to ensure that the other arms of the state to deal with these matters, can only result

and M. Kelly, 'Revisiting and Revising the Political Question: Lane v Halliburton and the Need to Adopt a Case-Specific Political Question Analysis for Private Military Contractor Cases', 29 Mississippi College School of Law Review (2010), 219-240, at 224 (suggesting that not every political question invokes the political question doctrine).

129 Barkow, supra note 9, at 243-244 (arguing that absolute deference is expected in cases involving political questions). See also Doctors for Life, supra note 84, at 1414 (noting that the Constitution envisaged the Court would decide cases with important political consequences); President of the RSA $v$ SARFU, supra note 125, at 762 (noting that Section 167(4) confers exclusive jurisdiction to this Court in a number of crucial political areas).

130 See Seedorf and Sibanda, supra note 6 and Okpaluba, supra note 6.

131 Amidu, supra note 64, at 159. 
in jeopardy for our constitutional democracy. In this dispute I am not prepared to create a juristocracy and thus do more than that which I am mandated to do in terms of our constitutional model. ${ }^{132}$

In my view, the above observation is an acknowledgement by a South African court that a political question doctrine is indispensable to preserve South African constitutional democracy. Secondly, because there is a tendency by detractors to reject the political question doctrine as an American concept, this rejection is unfounded and simplistic at best. ${ }^{133}$ The political question doctrine, as Justice Kpegah puts it, is not developed from any specific provision of the United States Constitution. ${ }^{134}$ Instead, he correctly says it is a necessary derivative of the concept of separation of powers, which concept also underpins the South African Constitution. ${ }^{135}$ Kpegah teaches us the fact that it was "developed within the American jurisprudence should not give us goose pimples and make us averse to its application to our constitutional adjudication" because "a rose will always smell sweet even if it is called ammonia".136

I submit that Kpegah's observations are applicable to South Africa. It should not matter that the political question doctrine is associated with or has gained prominence in the jurisprudence of the United States. The focus of any examination of this doctrine should be on its utility and what it is designed to achieve, which is to preserve the separation of powers. What is more, the South African Constitution is underpinned by the concept of separation of powers, which suggests that South Africa is likely to experience similar separation of powers concerns and challenges as the other countries that have already developed a political question doctrine. ${ }^{137}$ Even though the Court has said 'no separation

132 Mazibuko v Sisulu, supra note 6, at 33.

133 See Rautenbach, supra note 1; T. Roux, 'Baker v Carr in South Africa, or How Political Questions Become Legal Questions, Address at the Conference on Law, Language and Politics in South Africa: The Impact of the Constitution (Johannesburg, 1 July 20o6); and N. Ntlama, 'The "Deference” of Judicial Authority to the State', 1 Obiter (2012), 133-142.

134 Amiduv President Kufuor, supra note 64, at 159.

135 Ibid.

136 Ibid.

137 See SAAPIL $v$ Heath 2001 (1) BCLR 77,86 (CC)(holding that there can be no doubt that our Constitution provides for such a separation, and that laws inconsistent with what the Constitution requires in that regard, are invalid); Certification Judgment, supra note 70, at 1298-1300; Western Cape Legislature v President of the RSA 1995 (10) BCLR 1289 (CC); De Lange $v$ Smuts 1998 (7) BCLR 779 (CC); Pharmaceutical Manufacturers Association of SA 2000 (3) BCLR 241,26o (CC); and Bernstein v Bester 1996 (4) BCLR 449, 499 (CC). 
of powers is absolute", 138 it has emphasised that "pursuant to constitutional principle vi the Constitution provides for a system of separation of powers among the three co-equal branches of government, in which checks and balances result in the imposition of restraints by one branch of government upon another". ${ }^{139}$ Further, the Court has invalidated legislation on the basis that it was in conflict with the separation of powers required by the Constitution. ${ }^{140}$ As a result it can be argued that the South African Constitution does not contemplate the taking by one branch of government functions which in essence belong to another branch. Hence, South Africa's constitutional system is not uniquely designed from those countries that have developed and applied the political question doctrine.

\subsection{In Response to Opponents of the Political Question Doctrine in South Africa}

There are some who have argued against the adoption of the political question doctrine in South Africa. ${ }^{141}$ I believe these arguments are misplaced because the doctrine already exists, but requires clarity and further development. For the reasons already articulated, I submit that it is also a misplaced view to suggest that this doctrine is an American concept. In his critical discussion of the application of the political question doctrine in South Africa, Rautenbach describes it as an American concept. ${ }^{142}$ He observes that "in its land of origin it is highly controversial and has after more than two hundred years not produced clear guidelines on how it must be applied". ${ }^{143}$ The fact that that doctrine is controversial in the United States is not a rational basis for South African courts not to consider it and adapt it to the South African context. There are many legal doctrines that South African courts have borrowed from abroad. ${ }^{144}$ Further, the fact that courts in the United States have not produced

138 Certification Judgment, supra note 70, at 1298-1300. See also De Lange v Smuts, supra note 137 , at 804 .

139 Certification Judgment, supra note 70, at 1299. See also SAAPIL, supra note 137 , at 85-86 (confirming the separation of powers concept in the South African Constitution).

140 See Executive Council, supra note 137 (invalidating the Local Government Transition Act 209 of 1993 on separation of powers grounds).

141 Rautenbach, supra note 1, at 28; Roux, supra note 133; and Ntlama, supra note 133.

142 Ibid.

143 Ibid.

144 For example, National Coalition for Gay and Lesbian Equality $v$ Minister of Home Affairs 2000 (1) BCLR 54 (incorporating the doctrine of ripeness as applied in the United States into South African law); Ferreira, supra note 6 at 98; Currie and De Waal, supra note 13 at 79-96; $R v$ Garnsworthy 1923 WLD 17 (importing the English doctrine of common purpose 
clear guidelines on how it ought to be applied is also not a good reason to discard any consideration of United States authorities on the matter. In fact, I believe this state of affairs presents an opportunity for South African courts to learn from the experiences in the United States and other countries that have applied it. ${ }^{145}$ As I have mentioned above, it is my view that the doctrine or some elements of it already form part of South African law, and thus looking at the experiences in other countries can allow South African courts to develop it further as contemplated by Justice Ackerman in De Lange $v$ Smuts No and Others when he said:

I have no doubt that over time our courts will develop a distinctively South African model of separation of powers, one that fits the particular system of government provided for in the Constitution and that reflects a delicate balancing, informed both by South Africa's history and its new dispensation, between the need, on the one hand, to control government by separating powers and enforcing checks and balances and, on the other, to avoid diffusing power so completely that the government is unable to take timely measures in the public interest. ${ }^{146}$

If courts were to adhere to Rautenbach's suggestion, they would miss the opportunity to develop a clear political question doctrine from the principle of separation of powers as suggested by Ackerman. In my view, such development should require a clear and acceptable principle to jurisprudentially guide courts to determine whether to hear cases involving political questions. Further, I submit that an examination of the constitutional experiences in the United States (and other countries like Ghana, Nigeria, Israel and Uganda) offers South Africa an opportunity to confront once and for all the political question doctrine as developed and applied by the United States federal courts and determine how relevant it might be to the South African circumstance

into south African criminal law); See also Swissbourgh Diamond Mines $v$ Government of the RSA [1998] JOL 4144 (T) (holding that the act of state doctrine is applicable to South Africa as it is to the United States; and that the judicial branch of government ought to be astute in not venturing into areas where it would be in a judicial no man's land).

145 For a discussion of the political question doctrine in Israel, see M. Cohn, 'Form, Formula And Constitutional Ethos: The Political Question/Justiciability Doctrine in three Common Law Systems', 59 A Journal of Comparative Law (2011), 675-713; and Jabotinsky v. Weitzmann, HCJ 65/51 (1951).

146 De Lange v Smuts No, supra note 137 at para. 6 o. 
instead of the selective application of other American doctrines. ${ }^{147}$ This approach has worked well in Uganda, Israel, Nigeria and Ghana where the courts have adopted and modified the political question doctrine to fit the system of government contemplated in their constitutions.

Another of Rautenbach's main objections to the political question doctrine is that its application in South Africa would be in conflict with the supremacy of the Constitution, as contemplated by section 2 of the Constitution. ${ }^{148} \mathrm{He}$ argues that the supremacy clause does not permit the exclusion of any action from judicial review. ${ }^{149}$ While there is some merit to this argument, it is misplaced when one considers the full picture of the South African Constitution. If section 2 and perhaps read with section $167(3)^{150}$ of the Constitution is seen as implying that the Court has a special guardianship role in constitutional interpretation and enforcement, then it could equally be said that it (the Court) alone must have the final say in all constitutional questions in South Africa. This is hardly a true reflection of the South African constitutional scheme. I say this with a clear benefit in mind of section 167(3) of the Constitution, which entrusts the Court as the highest court on constitutional matters and the power to finally decide whether a matter is a constitutional matter. My point is that this is not the entire picture of the envisaged constitutional scheme.

Based on the doctrine of coordinate construction, Fisher and Devins argue that elected branches have both the authority and the competence to engage in constitutional interpretation. ${ }^{151}$ According to this view, 'the elected branches participate before the courts decide and they participate afterwards as well... the process is circular, turning back on itself again and again until

147 See, for example, Swissbourgh, supra note 144 at 108 (adopting the act of state doctrine from the United States Supreme Court). There are other justiciability doctrines such as ripeness, advisory opinion mootness that have been discussed and applied in South Africa. Free, supra note 38; Yoshino, supra note 3; Currie and De Waal, supra note 13, at 79-96.

148 Section 2 of the South African Constitution provides that "this Constitution is the supreme law of the Republic; law or conduct inconsistent with it is invalid, and the obligations imposed by it must be fulfilled".

149 Rautenbach, supra note 1, at 28.

150 Section $167(3)$ provides that "The Court - is the highest court in all constitutional matters". At the time of going to press, section 167(3) was amended by the Constitutional Seventeenth Amendment Act 2012 to read: "the Constitutional Court is the highest court of the Republic... and may decide constitutional matters and any other matter, if the Constitutional Court grants leave to appeal... and makes the final decision whether a matter is within its juridiction".

$15^{1}$ Fisher and Devins, supra note 12, at 10. 
society is satisfied with the outcome.152 Kanyeihamba shared this view when he declared in the landmark case of Tinyefuza that the constitutional platform is to be shared among the three arms of government, and that courts need to bear in mind the judgments of other repositories of constitutional power concerning the scope of their authority and the necessity for each to keep within its powers, including the courts themselves. ${ }^{153}$ South African academics such as Currie and de Waal agree with Fisher and Devins and Kanyeihamba. They observe that "while the courts have the final word they are by no means solely responsible for interpreting the Constitution". ${ }^{154}$ Similarly, Ngcobo agrees that the South African constitutional design contemplates interaction among the three branches of govern when he spoke of the "constitutional dialogue" and dismissed the perceived notion that "when courts strike down legislation it becomes the end of the matter". ${ }^{155}$ To the contrary, he argues that a judicial finding of invalidity is merely the beginning of a dialogue among the three branches of government. ${ }^{156}$ Ngcobo sees this dialogue as rooted in the shared obligation among all branches of government to uphold the Constitution". ${ }^{157}$ Others like Devenish observe that the "Court is not the ultimate protector of democracy". ${ }^{158}$ Clearly, for these academics and jurists, the South African judiciary shares responsibility for interpreting the Constitution with the elected branches of government.

Therefore, contrary to Rautenbach I believe that the preferred interpretation of section 2 read with section 167 of the Constitution as amended is that the Court has authority to adjudicate constitutional issues only when there are properly within its jurisdiction, and that it shares the responsibility for interpreting the Constitution with other branches of government. Moreover, the jurisdiction of court in section 34 of the Constitution is limited to those

\footnotetext{
$15^{2}$ Ibid., at 10.

153 Tinyefuza, supra note 6, at 13. See also M. Mhango, 'Transformation and the Judiciary', in C. Hoexter and M. olibier (eds), The Judiciary in South Africa (Cape Town, Juta, 2014), at pp. 91-97.

154 See Currie and De Waal, supra note 13, at 394 footnote 184 (commenting on the comments by Justice Chalskalson in Western Cape Legislature, supra note 193).

155 S. Ngcobo, 'South Africa's Transformative Constitution: Towards an Appropriate Doctrine of Separation of Powers', 1 Stellenbosch Law Review (2011), 37-49, at 41, 48 (arguing that the constitutional dialogue is the underpinning and defining feature of South African separation of powers).

156 Ibid.

157 Ibid.

158 Devenish, supra note 81, at 64 .
} 
disputes that can be resolved by the application of legal principles. ${ }^{159}$ It is my submission that section 2 does not bar courts from applying the political question doctrine just like it does not under the supremacy clauses in the constitutions of Uganda, Ghana, and the United States. The common feature in the constitutions of these countries is that they all declare their constitutions supreme law, and yet the highest courts in those countries have ruled that the political question doctrine is applicable. What is more, these constitutions (unlike the United States) are fairly new having been adopted in the 1990s like the South African Constitution. Thus, I fail to understand the uniqueness, which seems to be suggested by Rautenbach, of the supremacy of the South African Constitution that would prevent the application of the political question doctrine.

It is clear from the discussions of the case law from Ghana, Uganda and the United States that courts frequently apply the political question without compromising the supremacy clause in the constitutions of those countries. To reject the political question doctrine as being contrary to section 2 of the South African Constitution is to suggest that section 2 conflicts with the principle of separation of powers, which is the genesis of the political question doctrine. This is undoubtedly incorrect because the two principles coexist, and there is no reason the political question doctrine, as articulated in the countries discussed, cannot be applied in harmony with the supremacy clause in South Africa. Notwithstanding the supremacy clause, I agree with Kpegah that there is an inherent suggestion in the Constitution (including the South African Constitution in my view) that the policy which should inform any legislation and desire to enact such legislation are matters for the elected branches to decide. ${ }^{160}$ I believe that those policy decisions should not concern the judiciary because the elected branches have discretion and the "province of the judiciary is not to inquire how the elected branches perform duties in which they have discretion". 161

Finally, Rautenbach maintains that it would make no sense to adopt the political question doctrine in South Africa because of the critical remarks of

\footnotetext{
159 See Kolbatschenko, supra, at 120. See also Doctors for Life, supra note 68, at 1399 (discussing the threshold question of whether the Court has jurisdiction to interfere during the legislative but before a bill is signed into law, thereby confirming my proposition that the Court has authority to adjudicate constitutional issues that are properly within its jurisdiction).

160 See Amidu v President Kufuor, supra note 64 at 154.

161 Marbury, supra note 6 at 170.
} 
Henkin". ${ }^{162}$ In his 1976 article, Henkin contends that the political question doctrine does not exist. ${ }^{163} \mathrm{He}$ concludes that the political question doctrine is an unnecessary packaging of several established doctrines, but is no more than the sum of its parts and courts should do away with them. ${ }^{164}$ The problem with Rautenbach's reliance on Henkin is that he fails to acknowledge that many other prominent legal scholars support the application of the political question doctrine and have discredited Henkin's views. ${ }^{165}$ Clearly, it would be irrational to abandon an important legal principle like the political question doctrine solely on the basis that one prominent academic is critical of it. Moreover, Rautenbach fails to recognise that even after Henkin's article was published, a plurality of the Supreme Court in Goldwater v Carter ${ }^{166}$ expressly invoked the doctrine to avoid adjudicating a constitutional challenge by several members of Congress to the President's unilateral notice of termination of a mutual defence treaty with China. ${ }^{167}$

Other opponents of the political question have dismissed the application of the doctrine in South Africa on the basis that the Constitution does not commit any issue of constitutional interpretation to a coordinate branch of government for final decision. ${ }^{168}$ This argument is not valid. The fact that the Constitution is underpinned by the concept of separation of powers means that the Constitution commits particular matters to specific branches of government. In Kaunda, Justice O'Regan seems to agree that the Constitution committed the conduct of foreign affairs to the executive branch. She observed that "a variety of constitutional provisions including those that state that the President is responsible for receiving and recognising foreign diplomatic and consular representatives, ${ }^{169}$ appointing ambassadors, plenipotentiaries and

\footnotetext{
162 L. Henkin, 'Is There a "Political Question” Doctrine?', 85 Yale Law Journal (1976), 597-625.

163 Ibid., at $598-599$.

164 Ibid., at 622.

165 See Redish, supra note 3 (generally arguing that the political question doctrine does exist and is critical of Henkin's views but suggests that the doctrine should not exist); Tushnet, supra note 6, at 1203-1208; H. Wechsler, 'Toward Neutral Principles of Constitutional Law', 73 Harvard Law Review (1959), 1-35, at 6-9; and O.P. Field, 'The Doctrine of Political Questions in the Federal Courts' 8 Minnesota Law Review (1924) 485-512, at 512; Mulhern, supra note 6, at 104-124; Seidman, supra note 26 at 449; and C. Carter, 'Halliburton Hears A Who? Political Question Doctrine Developments in the Global War on Terror and Their Impact on Government Contigency Contracting', 201 Military Law Review (2009), 86-131.

166444 U.s. 996 (1979).

167 Redish, supra note 3, at 1032.

168 Roux, supra note 133 .

169 See section $84(2)(\mathrm{h})$ of the Constitution.
} 
diplomatic and consular representatives", ${ }^{170}$ suggests that the Constitution commits the conduct of foreign affairs to the executive branch. ${ }^{171}$ O'Regan claims that "this is hardly surprising". ${ }^{172}$ Justice Moseneke in Outa agreed with O'Regan and said the following:

Where the Constitution or valid legislation has entrusted specific powers and functions to a particular branch of government, courts may not usurp that power or function by making a decision of their preference. That would frustrate the balance of power implied in the principle of separation of powers. The primary responsibility of a court is not to make decisions reserved for or within the domain of other branches of government, but rather to ensure that the concerned branches of government exercise their authority within the bounds of the Constitution. This would especially be so where the decision in issue is policy-laden as well as polycentric. ${ }^{173}$

O'Regan and Moseneke's pronouncements above are an acknowledgement that the Constitution commits certain provisions to the various arms of government. In his concurring opinion in Outa Froneman views the Constitution in the same way. He remarked that "it is a breach of separation of powers for a court to intrude, by granting an interdict against government, upon the formulation and implementation of policy, a matter that resides in the heartland of national executive function."174

Since its emergence in Marbury, the political question doctrine has been applied in the United States. Due to its prominence, the political question doctrine has been adopted and applied in various forms in African countries such

\footnotetext{
170 See section $84(2)$ (i) of the Constitution.

171 Kaunda, supra note 78 , at 1073.

172 Ibid. See also Harksen $v$ President of the RSA 2000 (5) BCLR 478 (CC) (confirming that matters of foreign affairs are committed to the legislative and executive branches).

173 Outa, supra note 25, at para. 63.

174 Ibid., para. 84. There are other matters in the Constitution that are committed to the elected branches of government. See President of the RSA $v$ Hugo 1997 (6) BCLR 708 (CC) (recognizing that the exercise of pardon powers is committed to the executive branch); Glenister, supra note 100 at 696 (cc) (holding that elected branches of government are free to decide where to locate a specialized corruption-fighting unit).
} 
as Nigeria, Uganda and Ghana. In South Africa, its consideration or application has been problematic. The problem is that the Court has failed to articulate and develop a clear constitutional scheme to adjudicate political questions. It is submitted that just as the Court in Fedsure ${ }^{175}$ created and articulated the doctrine of legality as an incident of the principle of rule of law contained in section 1 of the Constitution, the same must happen in relation to the political question doctrine under the principle of separation of powers. In the same way that the doctrine of legality has been clarified over the years since it was first articulated, the Court must develop and clarify the political question doctrine, which as I have argued is already part of South African constitutional law. The Court must do this to prevent jurisdictional problems affecting the three arms of government that are bound to emerge in the future. More importantly, the Court must do this because it is my firm view that the framers of the South African Constitution did not intend to anoint and ordain the judiciary with unlimited power.

\section{Acknowledgements}

I would like to thank Prof. Dyani Mhango for listening to my thoughts during the months of me writing this paper and for her useful comments. I would also like to thank Mr. Sanele Sibanda and Prof. Vanessa MacDonnell for their useful critical comments on an earlier draft of this paper.

175 Fedsure Life v Greater Johannesburg Metropolitan Council 1998 (12) BCLR 1458, 1482 (CC). See also Pharmaceutical, supra note 13. 